\title{
How Effective Is Central Bank Forward Guidance?
}

\author{
Clemens J.M. Kool and Daniel L. Thornton
}

This paper investigates the effectiveness of forward guidance for the central banks of New Zealand, Norway, Sweden, and the United States. The authors test whether forward guidance improved market participants' ability to forecast future short-term and long-term rates relative to several benchmarks. They find some evidence that forward guidance improved market participants' ability to forecast short-term rates over relatively short forecast horizons for New Zealand, Norway, and Sweden but not the United States. However, the effects are typically small and frequently not statistically significant. Moreover, in no case are the results uniform across the benchmarks used. In addition, the authors find evidence of convergence of survey forecasters for New Zealand but less so for the other countries and no evidence of convergence for the United States. (JEL E52, E43, E47)

Federal Reserve Bank of St. Louis Review, Fourth Quarter 2015, 97(4), pp. 303-22.

\section{INTRODUCTION}

Monetary policy has become increasingly transparent in developed economies since the late 1980s. Some economists argue that transparency increases the efficacy of monetary policy (e.g., Woodford, 2003, 2005, and Svensson, 2006, 2007). Indeed, former Federal Reserve Chairman Bernanke (2007) suggests that increased transparency improves financial and economic performance by anchoring long-term inflation expectations, reducing economic and financial uncertainty, and encouraging financial markets to anticipate policy actions, which reinforces the effectiveness of those actions. The idea that greater transparency necessarily enhances the efficacy of monetary policy is not shared by all. For example, Amato, Morris, and Shin (2002); Morris and Shin (2002); Thornton (2003); Mishkin (2004); Walsh (2007, 2008); Gosselin, Lotz, and Wyplosz (2006); and Kool, Middeldorp, and Rosenkranz (2011) suggest that transparency is not necessarily beneficial for a variety of reasons.

The most recent innovation in monetary policy transparency is forward guidance (FG). FG can take the form of information provided by the central bank about the future path for

\footnotetext{
Clemens J.M. Kool is deputy director of the CPB Netherlands Bureau for Economic Policy Analysis, The Hague, and professor of finance and financial markets at Utrecht University, the Netherlands. Daniel L. Thornton, a former vice president and economic advisor at the Federal Reserve Bank of St. Louis, is president of D.L. Thornton Economics, LLC. The authors thank Andreas Worms and the referees for helpful suggestions and comments and Sean Grover and Yang Liu for valuable research assistance.

(c) 2015, Federal Reserve Bank of St. Louis. The views expressed in this article are those of the author(s) and do not necessarily reflect the views of the CPB Netherlands Bureau for Economic Policy Analysis, the Federal Reserve System, the Board of Governors, or the regional Federal Reserve Banks. Articles may be reprinted, reproduced, published, distributed, displayed, and transmitted in their entirety if copyright notice, author name(s), and full citation are included. Abstracts, synopses, and other derivative works may be made only with prior written permission of the Federal Reserve Bank of St. Louis.
} 


\section{Kool and Thornton}

its policy rate or other economic variables - which the central bank assumes will provide useful insight about its reaction function (e.g., Campbell et al., 2012). However, as articulated by Woodford $(1999,2001,2012), \mathrm{FG}$ is a policy that can be used to increase the efficacy of the central bank's interest rate policy. Woodford (2012) argues that if policymakers could credibly commit to a path for the future policy rate, they would have a much larger effect on long-term yields. The idea that the central bank's interest rate policy could be more effective if policymakers were to commit to a path for short-term rates (see, e.g., Woodford, 1999, 2001, 2012; Rosenberg, 2007; and Svensson, 2007) motivated several central banks to adopt FG policies. As was the case with inflation targeting, the Reserve Bank of New Zealand (RBNZ) took the lead, adopting its FG policy in 1997. The Norges Bank and the Riksbank followed in 2005 and 2007, respectively, and the Czech National Bank adopted FG in 2008. In recent years, more countries have turned to a form of FG; for example, Canada did so in 2009 and the United Kingdom did so in 2013. The Federal Open Market Committee (FOMC) began using implicit FG in August 2003 but discontinued the practice in December 2005. The FOMC adopted FG again in December 16, 2008, when it reduced its policy rate to essentially zero.

This paper contributes to the literature by investigating the effectiveness of FG for New Zealand, Norway, Sweden, and the United States. ${ }^{1}$ Specifically, we test whether FG increased the predictability of short-term and long-term interest rates. Interest rates should have been more predictable if the central banks' FG provided useful information about the future path of short-term rates. In addition, if FG provided useful information about future interest rates, there should have been an increase in convergence of interest rate forecasts among individual forecasters. Hence, we also test for increased convergence among forecasts. We use survey forecasts from Consensus Economics (CE).

The paper proceeds as follows. The next section reviews the theory of FG and alternative views on the desirability and effectiveness of FG. Previous empirical investigations of the effectiveness of FG are reviewed in the third section. The fourth section presents our methodology and analysis of the effectiveness of FG, and the fifth section concludes.

\section{FORWARD GUIDANCE: THE THEORY}

The use of FG to increase the effectiveness of central banks' interest rate policy is based on Woodford's $(1999,2001)$ concept of optimal policy inertia. Specifically, Woodford (2001, p. 308) suggests that

The effectiveness of changes in central-bank targets for overnight rates in affecting spending decisions (and, hence, ultimately pricing and employment decisions) is wholly dependent upon the impact of such actions upon other financial-market prices, such as longer-term interest rates, equity prices, and exchange rates. These are plausibly linked, through arbitrage relations, to short-term interest rates most directly affected by centralbank actions: but it is the expected future path of short-term rates over coming months and even years that should matter for the determination of these other asset prices...

The reason is probably fairly obvious in the case of longer-term interest rates; the expectations theory of the term structure implies that these should be determined by expected future short-term rates. ${ }^{2}$ 
Woodford suggests that the central bank's interest rate policy will be more effective (i.e., have a larger effect on longer-term rates) if the central bank can credibly commit to maintaining its policy rate longer than it normally would-the so-called Woodford period. ${ }^{3}$ That is, the central bank's FG must cause market participants to alter their expectations for the path of the policy rate and, consequently, short-term interest rates generally. Woodford (2012) notes that to be effective, a central bank's FG policy must be credible: If the commitment is not credible, FG cannot cause market participants to revise their expectations for the path of short-term rates.

Rudebusch and Williams (2008) use the link between expected future short-term rates and long-term rates in a New Keynesian model to demonstrate that publishing the forecast of the interest rate path makes the private agents' estimate of the central bank's reaction function more precise. However, not everyone believes that FG necessarily increases the efficacy of monetary policy. FG could disrupt financial markets if economic agents place too much confidence in the announced policy path and disregard other information relevant for the future path of rates. The result could be herding behavior and overreaction to policy announcements. Morris and Shin (2002) demonstrate conditions where higher transparency can drive expectations away from fundamentals. Kool, Middeldorp, and Rosenkranz (2011) show that under near-risk-neutrality of market participants, more central bank information may lead to crowding out of private information, thereby reducing forecast precision. Walsh (2007) and Gosselin, Lotz, and Wyplosz (2009) demonstrate that the optimal degree of transparency in a New Keynesian model depends on the central bank's ability to forecast demand and supply shocks, while Brzoza-Brzezina and Kot (2008) show that the benefits of publishing interest rate forecasts are marginal once macroeconomic forecasts are provided. Mishkin (2004), Blinder and Wyplosz (2004), Goodhart (2005), and Gersbach and Hahn (2008a,b) raise other theoretical concerns with increased transparency, while Moessner and Nelson's (2008) literature review (including Kohn 2005, 2008; Issing, 2005; Rosenberg, 2007; Bergo, 2006; and Archer, 2005) found that central bankers are concerned about the ability of policymakers to reach a consensus on the interest rate path. ${ }^{4}$ Indeed, Thornton (2015a) finds that the Fed's FG did not yield a consensus among FOMC participants about the path for the funds rate.

\section{FG: PREVIOUS EMPIRICAL EVIDENCE}

Empirical investigations of the effects of FG have been relatively limited. Most research has focused on New Zealand because of its relatively long period of providing FG. Two different empirical approaches can be distinguished. One strand uses the event-study methodology to evaluate the effect of FG announcements on short-term and long-term interest rates and interest rate futures. The other strand investigates the effect of FG on interest rate predictability. We follow this second approach.

There has been a large number of event-study investigations of the effectiveness of FG (e.g., Andersson and Hofmann, 2010; Moessner and Nelson, 2008; Ferrero and Secchi, 2007; Mirkov and Natvik, 2013; Drew and Karagedikli, 2008; Karagedikli and Siklos, 2008; and Moessner, 2013), which have yielded mixed results. For example, Andersson and Hofmann (2010) found "some mild support for the notion that the publication of an interest rate path 
forecast may enhance the central bank's leverage over medium term (5-year) interest rates." Using a similar methodology, Moessner and Nelson (2008) found that FG announcements had a relatively small effect on expectations of future rates and no evidence that policy rate changes that deviate from prior FG announcements unsettle the markets. Ferrero and Secchi (2007) found small responses of 3- and 12-month-ahead 3-month futures rates; however, they found that "the change in market interest rates in the period between two publications of the interest rate path is similar to the revision of the published path" (p. 3). They interpret this finding as evidence that "market operators have well understood the conditionality of the central bank's projections" (Ferrero and Secchi, 2007, p. 30). ${ }^{5}$ In contrast with these findings, Drew and Karagedikli (2008) find that unexpected changes in the RBNZ's policy rate are associated with large changes in market yields at short horizons but not at long horizons. Karagedikli and Siklos (2008) found significant high-frequency effects of FG announcements on the New Zealand exchange rate, and Moessner (2013) found relatively large announcement effects for six FOMC FG announcements.

Overall, the evidence from event studies suggests that, at short horizons, FG announcements have an impact, be it relatively small, on market rates. However, any test of the effect of FG is a joint test, conditional on the correct identification of the surprise measures. Such identification is difficult because market rates respond to news every day (see Thornton, 2014). In the same vein, both Woodford (2012) and Thornton (2015b, in similar words) note that every FOMC policy statement "contains a summary of the FOMC's view of the outlook for real activity and inflation, and a statement indicating greater perceived downside risk or less worry about inflation on the horizon could be a reason to reduce the probability assigned to an increase in the funds rate anytime soon" (Woodford, 2012, p. 257). The same is true for the FG provided by the other central banks.

The second strand of empirical investigations focuses on how FG affects interest rate predictability. Our analysis is closely related to that of McCaw and Ranchhod (2002), Turner (2006), and Goodhart and Lim (2011). McCaw and Ranchhod (2002) find evidence that the RBNZ's interest rate projections do not significantly outperform a random walk. Turner (2006) compares RBNZ forecasts to survey forecasts and finds no difference in performance at the 3-month horizon but some improvement for the RBNZ at the 12-month horizon. Goodhart and Lim (2011) found that the RBNZ forecasts have significant predictive power for the 1quarter-ahead money market rate and some predictive power for the 2-quarter-ahead money market rate, but none for longer horizons. They found similar results for the United Kingdom using market forecasts derived from the yield curve. However, they also found that forecasts systematically underpredict rates during periods with rising rates and overpredict rates during periods with falling rates and suggest that the forecasting improvement may be a consequence of mean-reverting behavior of the macroeconomy.

\section{THE EFFECTIVENESS OF CENTRAL BANK FG}

Our analysis extends the existing evidence by investigating whether survey forecasts of interest rates improved significantly after the adoption of FG. FG could increase the predict- 
ability of short-term rates by reducing market participants' uncertainty about the path of the short-term policy rate. Whether FG affects longer-term interest rates depends on its ability to alter market participants' expectation for the path of short-term rates. This can be done by changing the path for the rate by extending the horizon for the path. However, when the policy rate is at its zero lower bound, this can be done only by extending the time the policy rate will remain at zero. The extent of the effect on market expectations depends on the perceived strength and credibility of the central bank's commitment to its announced path for future interest rates. Also, it may depend on whether the FG is time dependent or state contingent. When FG is time dependent, the central bank commits to a particular path for a given time horizon. If the time horizon is longer than market participants had previously expected and the commitment is credible, time-dependent FG should effectively move rates in the intended direction.

State-contingent FG should also affect longer-term rates, as recommended by the "optimal policy literature." However, the period that the path will be maintained is, strictly speaking, undetermined. It depends on market participants' expectation for when the state-contingency criterion will be met. Of course, policymakers understand that their FG policy cannot affect longer-term yields if it does not cause market participants to reduce their expected path for short-term rates-which, if the policy rate is at its zero lower bound, can be done only by lengthening the period that market participants expect the path for the policy rate to be maintained at that zero lower bound. Consequently, given that the objective is to have a larger effect on longer-term yields, policymakers are likely to set a contingency criterion they believe will achieve this objective.

The FG provided by the central banks of New Zealand, Norway, and Sweden is time dependent. Specifically, these banks provide interest rate forecasts up to a three-year horizon. The RBNZ first began publishing a path for the 90-day bill rate in its December 1997 quarterly Monetary Policy Statement in an attempt to provide FG about future monetary policy (e.g., Detmers and Nautz, 2012). ${ }^{6}$ Projections are for the average daily interest rate in the calendar quarter under consideration, including the current quarter. The Norges Bank first started to publicly communicate model-based interest rate projections in its October/November 2005 Monetary Policy Report. Consequently, the fourth quarter of 2005 is assumed to be the start of Norway's FG. Interest rate projections are for the daily average of the key policy rate in a quarterly calendar; the key policy rate is the sight deposit rate, the rate at which banks can deposit at the Norges Bank in a calendar quarter. The projections are published in the Monetary Policy Report, which was issued three times per year over the period of the analysis. ${ }^{7}$ Typically the Monetary Policy Report contains projections for the remainder of the current year plus the three subsequent years. In Sweden, the Riksbank began publishing model-based projections for the repo rate-its policy rate-in its February 2007 Monetary Policy Report. The repo rate projections are quarterly averages of the daily rate over a three-year horizon. They are typically released six times per year, three times in the Monetary Policy Report and three times in the Monetary Policy Update.

For the United States, the FOMC first provided FG during the August 2003-December 2005 period. ${ }^{8}$ The FOMC reduced the funds rate target to the then historically low level of 
1.0 percent at its June 2003 meeting and at its August 2003 meeting announced that "the Committee believes that policy accommodation can be maintained for a considerable period" (emphasis added).9,10 The "considerable period" language was used through the remainder of 2003. At its January 2004 meeting, the FOMC modified the language to "the Committee believes that it can be patient in removing its policy accommodation." At its May 2004 meeting, the FOMC signaled its intention to start increasing the funds rate target, saying that "policy accommodation can be removed at a pace that is likely to be measured." The "measured pace" language appeared in every statement until December 2005, even though the FOMC increased the target by 25 basis points at each of the next 12 meetings. In our view, the FOMC's FG was time dependent during this period; however, the time path for the target was vague. Nevertheless, the language was clearly intended to suggest that the target would be at 1.0 percent for a much longer period than market participants might normally have anticipated.

The FG the FOMC initiated in December 2008 was time dependent but vague: "[T]he Committee anticipates that weak economic conditions are likely to warrant exceptionally low levels of the federal funds rate for some time." "[F] or some time" was quickly changed to "for an extended period." The intent was clear. The FOMC was trying to lengthen the period that market participants would expect the funds rate to remain at effectively zero.

The FOMC adopted a specific time-dependent FG policy at its August 2011 meeting, saying the funds rate would be maintained at zero "at least through mid-2013." The period was extended to "at least through late 2014" at the January 2012 meeting and to "at least through mid-2015" at the September 2012 meeting. The FOMC moved to state-contingent FG at its December 2012 meeting.

\section{FG and the Predictability of Interest Rates}

Our methodology is designed to investigate whether interest rate forecasts improved significantly following the adoption of FG by the central banks of New Zealand, Norway, Sweden, and the United States. If FG is effective, there should be a significant improvement in market participants' ability to forecast future short-term interest rates. ${ }^{11}$ Hence, we test whether the conditional expectation of the rate at time $t$ for horizon $h$ improves following the central bank's adoption of FG. We use (CE) survey data to measure (conditional) market expectations for these countries. CE forecasts are available monthly for 3-and 12-month horizons. We present the results for the mean 3-month and 12-month forecasts for the 3-month bill rate and the 10-year bond yield. The sample period for each country is determined by the availability of the CE forecasts. The samples begin in December 1994, June 1998, January 1995, and January 1990 for New Zealand, Norway, Sweden, and the United States, respectively. The samples end in October 2013.

The analysis begins by testing whether the CE forecast errors decrease after the adoption of FG. Specifically, we estimate the equation

$$
L\left(e_{t, m, h}^{j}\right)=\delta_{0}+\delta_{1} D_{u m}^{j}+v_{t},
$$

where $L\left(e_{t, m, h}^{j}\right)$ denotes the value of a given loss function of the forecast error at time $t$ of country $j$ for maturity $m=3$-month, 10 -year, and forecast horizons (in months) $h=3$-month, 
Kool and Thornton

\section{Table 1}

\section{Changes in Survey Forecast Performance}

\begin{tabular}{|c|c|c|c|c|c|}
\hline \multirow[b]{3}{*}{ Maturity, horizon } & \multirow[b]{2}{*}{ NZ } & \multirow[b]{2}{*}{ NW } & \multirow[b]{2}{*}{ SW } & \multicolumn{2}{|c|}{ US } \\
\hline & & & & 2003-05 & 2008-13 \\
\hline & $\hat{\delta}_{1}(\mathrm{SE})$ & $\hat{\delta}_{1}(\mathrm{SE})$ & $\hat{\delta}_{1}(\mathrm{SE})$ & $\hat{\delta}_{1}(\mathrm{SE})$ & $\hat{\delta}_{2}(\mathrm{SE})$ \\
\hline \multicolumn{6}{|c|}{ Panel A: Absolute errors } \\
\hline$m=3 m, h=3 m$ & $\begin{array}{c}-0.474^{* *} \\
(0.146)\end{array}$ & $\begin{array}{c}-0.194 \\
(0.132)\end{array}$ & $\begin{array}{c}0.004 \\
(0.107)\end{array}$ & $\begin{array}{c}-0.271^{* *} \\
(0.067)\end{array}$ & $\begin{array}{c}-0.373^{* *} \\
(0.061)\end{array}$ \\
\hline$m=3 m, h=12 m$ & $\begin{array}{c}0.072 \\
(0.287)\end{array}$ & $\begin{array}{c}-0.286 \\
(0.331)\end{array}$ & $\begin{array}{c}-0.050 \\
(0.290)\end{array}$ & $\begin{array}{c}-0.841^{* *} \\
(0.171)\end{array}$ & $\begin{array}{c}-1.078^{* *} \\
(0.188)\end{array}$ \\
\hline$m=10 y, h=3 \mathrm{~m}$ & $\begin{array}{c}-0.287^{*} \\
(0.118)\end{array}$ & $\begin{array}{c}-0.007 \\
(0.067)\end{array}$ & $\begin{array}{c}0.003 \\
(0.091)\end{array}$ & $\begin{array}{c}-0.159 * \\
(0.066)\end{array}$ & $\begin{array}{c}-0.024 \\
(0.091)\end{array}$ \\
\hline$m=10 y, h=12 m$ & $\begin{array}{c}-0.259 \\
(0.173)\end{array}$ & $\begin{array}{c}-0.064 \\
(0.173)\end{array}$ & $\begin{array}{c}-0.076 \\
(0.203)\end{array}$ & $\begin{array}{c}-0.314^{*} \\
(0.148)\end{array}$ & $\begin{array}{c}0.078 \\
(0.212)\end{array}$ \\
\hline \multicolumn{6}{|c|}{ Panel B: Squared errors } \\
\hline$m=3 m, h=3 m$ & $\begin{array}{c}-0.624 \\
(0.327)\end{array}$ & $\begin{array}{c}-0.309 \\
(0.307)\end{array}$ & $\begin{array}{c}0.163 \\
(0.232)\end{array}$ & $\begin{array}{c}-0.366^{* *} \\
(0.104)\end{array}$ & $\begin{array}{c}-0.403^{* *} \\
(0.104)\end{array}$ \\
\hline$m=3 m, h=12 m$ & $\begin{array}{c}0.343 \\
(1.070)\end{array}$ & $\begin{array}{c}-1.242 \\
(1.331)\end{array}$ & $\begin{array}{c}0.020 \\
(1.145)\end{array}$ & $\begin{array}{c}-2.708^{* *} \\
(0.596)\end{array}$ & $\begin{array}{c}-2.893^{* *} \\
(0.603)\end{array}$ \\
\hline$m=10 \mathrm{y}, h=3 \mathrm{~m}$ & $\begin{array}{c}-0.472^{*} \\
(0.197)\end{array}$ & $\begin{array}{c}-0.005 \\
(0.070)\end{array}$ & $\begin{array}{c}0.056 \\
(0.138)\end{array}$ & $\begin{array}{c}-0.206^{* *} \\
(0.065)\end{array}$ & $\begin{array}{c}-0.009 \\
(0.123)\end{array}$ \\
\hline $\mathrm{m}=10 \mathrm{y}, h=12 \mathrm{~m}$ & $\begin{array}{c}-0.430 \\
(0.348)\end{array}$ & $\begin{array}{c}-0.085 \\
(0.365)\end{array}$ & $\begin{array}{c}-0.311 \\
(0.500)\end{array}$ & $\begin{array}{c}-0.676^{* *} \\
(0.234)\end{array}$ & $\begin{array}{c}0.322 \\
(0.511)\end{array}$ \\
\hline
\end{tabular}

NOTE: The table reports estimates of $\delta_{1}$ and the corresponding standard errors (in parentheses) from the equation $L\left(e_{t, m, h}^{j}\right)=\delta_{0}+\delta_{1} D u m^{j}+v_{t}$, for four FG countries, $j=$ NZ, NW, SW, US, where NZ is New Zealand, NW is Norway, SW is Sweden, and US is the United States. The sample period starts in 1994:12 for New Zealand, in 1995:01 for Sweden, in 1998:06 for Norway, and in 1990:01 for the United States. The sample period ends in 2013:10. For the United States, the regression contains two dummy variables with coefficients $\delta_{1}$ and $\delta_{2}$, respectively. In Panel A, $L($.) is the absolute value of the CE forecast error; in Panel $B$, it is the squared CE forecast error. The regression uses forecast errors for two horizons, 3 months $(h=3 \mathrm{~m})$ and 12 months $(h=12 \mathrm{~m})$, and two rates, the 3-month bill rate $(m=3 \mathrm{~m})$ and 10-year bond rate $(\mathrm{m}=10 \mathrm{y})$. Dum $\mathrm{m}^{j}$ takes a value of $1 \mathrm{for}$ the FG period in country $j$ and zero otherwise. A negative value of $\hat{\delta}_{1}\left(\hat{\delta}_{2}\right)$ implies the absolute or squared forecast error during the FG period. **** indicate significance at the 5 percent/1 percent levels.

12-month. We use two loss functions $L($.$) , the absolute error and the squared error. Dum { }^{j}$ is a dummy variable that takes a value of 1 during the FG period in country $j$ and zero otherwise. If FG improved market participants' ability to forecast rates, the estimate of $\delta_{1}$ should be negative and statistically significant. Estimates of $\delta_{1}$ and corresponding standard errors corrected for heteroskedasticity are presented in Table 1 for the absolute forecast errors (Panel A) and the squared forecast errors (Panel B). ${ }^{12}$ For the United States, two dummy variables are used with coefficients $\delta_{1}$ and $\delta_{2}$, respectively, to reflect the two distinct FG periods.

The results provide mixed support for the efficacy of FG. Specifically, estimates of $\delta_{1}$ are negative and statistically significant for the 3 -month rate and the 10 -year yield at the 3 -month horizon for New Zealand using the absolute-error metric and for the 10-year yield at the 3-month horizon using the squared-error metric. For Norway and Sweden, no significant 
effects are found. For the United States in the first FG period, forecasting performance improves significantly for both rates and both horizons according to both metrics. In the second FG period, this is true only for the short rate.

The test results presented in Table 1 are based on the assumption that there was no fundamental change unrelated to FG in the data-generating process of interest rates. That is not necessarily the case, however. A prime candidate for such a fundamental change is the start of the global financial crisis when Lehman Brothers defaulted in September 2008. At that time, interest rates became more volatile for some period and, hence, more difficult to predict. To account for this influence, we exclude observations for the July 2008-January 2009 period for the 3-month-ahead forecasts and for the December 2007-January 2009 period for the 12-month-ahead forecasts. Results for New Zealand and the United States remain qualitatively unchanged. However, both for Norway and Sweden we now find negative and (in a few cases marginally) statistically significant $\delta_{1}$ coefficients for the 3-month bill rate at both the 3- and 12-month horizons.

Thus, accounting for increased volatility at the start of the financial crisis, we do find support that FG improved forecasting of the short rate for all four countries considered here. The evidence for the long rate is weak. For the United States, two caveats apply: First, while the size of the absolute and squared forecast errors in the 2003-2005 period is significantly below the long-term average, it is not significantly different from that in the years directly preceding FG from early 2002 onward and in the years directly following FG until mid-2007. This throws some doubt on the causal role of FG and suggests other factors may have been at work too. Second, the start of the second period of FG almost perfectly coincides with the fall of the U.S. short-term rate to almost zero. ${ }^{13}$

\section{FG and the Predictability of Interest Rates: Double Differencing}

To control for other factors that could have changed the data-generating process for interest rates and, consequently, changes in forecast performance over time, we use the doubledifference method. It allows assessment of CE forecasts before and after the introduction of FG relative to a benchmark. As is commonly done in the literature, we use the simple randomwalk forecast performance as a benchmark. ${ }^{14} \mathrm{We}$ also compare the forecasting performance of the FG countries with that of non-FG countries with similar characteristics. Since there is no compelling reason to select a specific country, we compare the forecasting performance of the FG countries relative to that of Australia, the United Kingdom, and Canada. ${ }^{15}$

Since U.S. FG is somewhat different in character than that in the other three countries, we relegate the empirical analysis for the United States to a separate section and focus on the other three countries first. We test whether the adoption of FG improved the CE forecasts relative to the respective benchmarks by estimating the equation

$$
d_{t, m, h}^{j, k}=L\left(e_{t, m, h}^{j}\right)-L\left(e_{t, m, h}^{k}\right)=\alpha+\beta D u m^{j}+\varepsilon_{t} .
$$

The dependent variable, $d_{t, m, h}^{j, k}$, is the difference in the forecast-error loss function of the FG central bank ( $j=\mathrm{NZ}$, NW, SW, where NZ is New Zealand, NW is Norway, and SW is Sweden) 
Kool and Thornton

\section{Table 2}

Relative Changes in Survey Forecast Performance: New Zealand

\begin{tabular}{|c|c|c|c|c|}
\hline \multirow[b]{2}{*}{ Maturity, horizon } & \multicolumn{4}{|c|}{ Benchmark } \\
\hline & RW & $A U$ & CA & UK \\
\hline \multicolumn{5}{|c|}{ Panel A: Absolute errors } \\
\hline$m=3 m, h=3 m$ & $\begin{array}{c}-0.091 \\
(0.112)\end{array}$ & $\begin{array}{c}-0.325 \\
(0.199)\end{array}$ & $\begin{array}{c}-0.046 \\
(0.200)\end{array}$ & $\begin{array}{c}-0.541^{* *} \\
(0.159)\end{array}$ \\
\hline$m=3 m, h=12 m$ & $\begin{array}{c}0.292 \\
(0.315)\end{array}$ & $\begin{array}{c}0.816 \\
(0.465)\end{array}$ & $\begin{array}{c}0.985^{*} \\
(0.424)\end{array}$ & $\begin{array}{c}-0.213 \\
(0.287)\end{array}$ \\
\hline$m=10 y, h=3 \mathrm{~m}$ & $\begin{array}{c}0.014 \\
(0.057)\end{array}$ & $\begin{array}{c}-0.055 \\
(0.119)\end{array}$ & $\begin{array}{c}-0.038 \\
(0.110)\end{array}$ & $\begin{array}{c}-0.249 \\
(0.138)\end{array}$ \\
\hline$m=10 y, h=12 m$ & $\begin{array}{c}-0.061 \\
(0.145)\end{array}$ & $\begin{array}{c}0.644^{* *} \\
(0.189)\end{array}$ & $\begin{array}{c}0.041 \\
(0.203)\end{array}$ & $\begin{array}{c}0.248 \\
(0.137)\end{array}$ \\
\hline \multicolumn{5}{|c|}{ Panel B: Squared errors } \\
\hline$m=3 m, h=3 m$ & $\begin{array}{c}-0.318 \\
(0.298)\end{array}$ & $\begin{array}{c}-0.503 \\
(0.375)\end{array}$ & $\begin{array}{c}-0.060 \\
(0.403)\end{array}$ & $\begin{array}{c}-0.768^{*} \\
(0.311)\end{array}$ \\
\hline$m=3 m, h=12 m$ & $\begin{array}{c}-0.207 \\
(1.009)\end{array}$ & $\begin{array}{c}2.022 \\
(1.481)\end{array}$ & $\begin{array}{c}2.971 \\
(1.578)\end{array}$ & $\begin{array}{c}-0.414 \\
(0.911)\end{array}$ \\
\hline$m=10 y, h=3 \mathrm{~m}$ & $\begin{array}{c}-0.069 \\
(0.079)\end{array}$ & $\begin{array}{c}-0.174 \\
(0.225)\end{array}$ & $\begin{array}{c}-0.127 \\
(0.183)\end{array}$ & $\begin{array}{c}-0.457^{*} \\
(0.213)\end{array}$ \\
\hline$m=10 y, h=12 \mathrm{~m}$ & $\begin{array}{c}-0.087 \\
(0.331)\end{array}$ & $\begin{array}{l}1.852^{* *} \\
(0.578)\end{array}$ & $\begin{array}{c}0.032 \\
(0.411)\end{array}$ & $\begin{array}{c}0.654 \\
(0.323)\end{array}$ \\
\hline
\end{tabular}

NOTE: The table reports estimates of $\beta$ and the corresponding standard errors (in parentheses) from the equation $d_{t, m, h}^{j, k}=L\left(e_{t, m, h}^{j}\right)-L\left(e_{t, m, h}^{k}\right)=\alpha+$ $\beta$ Dum $^{j}+\varepsilon_{t}$, for $j=\mathrm{NZ}$, where NZ is New Zealand. The sample period is 1994:12-2013:10. The left-hand-side variable is the difference in the loss function of the CE forecast errors for New Zealand interest rates relative to the loss function for benchmark $k$, for a given maturity $m$ and horizon $h$. The benchmark uses the naive random walk forecast errors $(k=\mathrm{RW})$ for New Zealand interest rates as well as the CE forecast errors for three nonFG countries, Australia $(k=\mathrm{AU})$, Canada $(k=\mathrm{CA})$, and the United Kingdom $(k=\mathrm{UK})$. In Panel A, the forecast error loss function $L($.) is the absolute value of the forecast error; in Panel $B$, it is the squared forecast error. The regression uses two interest rates, the 3 -month bill rate $(m=3 \mathrm{~m})$ and 10-year bond rate $(m=10 \mathrm{y})$, at two forecast horizons, 3 months $(h=3 \mathrm{~m})$ and 12 months $(h=12 \mathrm{~m})$. Dum ${ }^{j}$ takes a value of 1 for the FG period in New Zealand (1997:12-2013:10) and zero otherwise. A negative value of $\hat{\beta}$ implies CE forecast performance for New Zealand improved with the start of FG relative to the given benchmark. **** indicate significance at the 5 percent/ 1 percent levels.

relative to a benchmark ( $k=\mathrm{RW}, \mathrm{AU}, \mathrm{CA}, \mathrm{UK}$, where $\mathrm{RW}$ is random walk, $\mathrm{AU}$ is Australia, UK is the United Kingdom, and CA is Canada) for a given maturity $m$ and horizon $h$. The coefficient, $\beta$, is an estimate of the change in the relative forecasting performance following the adoption of FG. A negative estimate of $\beta$ indicates an improvement in CE forecasting performance relative to the benchmark. As before, both the absolute-error and squared-error loss functions are used.

New Zealand, Norway, and Sweden. The results for New Zealand (Table 2) provide little support for the efficacy of FG. Most coefficients are insignificant; however, there are three significantly negative $\beta$ coefficients, but only relative to the U.K. benchmark. Moreover, there are also three positive and statistically significant coefficients for the other three benchmarksall at the 12-month horizon. The RBNZ's policy rate and the 3-month rate were relatively 


\section{Table 3}

\section{Relative Changes in Survey Forecast Performance: Norway}

\begin{tabular}{|c|c|c|c|c|}
\hline \multirow[b]{2}{*}{ Maturity, horizon } & \multicolumn{4}{|c|}{ Benchmark } \\
\hline & RW & $A U$ & CA & UK \\
\hline \multicolumn{5}{|c|}{ Panel A: Absolute errors } \\
\hline$m=3 m, h=3 m$ & $\begin{array}{r}-0.109 \\
(0.079)\end{array}$ & $\begin{array}{c}-0.290^{*} \\
(0.130)\end{array}$ & $\begin{array}{c}-0.102 \\
(0.134)\end{array}$ & $\begin{array}{c}-0.188 \\
(0.114)\end{array}$ \\
\hline$m=3 m, h=12 m$ & $\begin{array}{c}-0.284 \\
(0.197)\end{array}$ & $\begin{array}{l}-0.867^{* *} \\
(0.313)\end{array}$ & $\begin{array}{c}-0.172 \\
(0.346)\end{array}$ & $\begin{array}{c}-0.374 \\
(0.317)\end{array}$ \\
\hline$m=10 y, h=3 m$ & $\begin{array}{c}0.017 \\
(0.047)\end{array}$ & $\begin{array}{c}0.043 \\
(0.080)\end{array}$ & $\begin{array}{c}0.027 \\
(0.058)\end{array}$ & $\begin{array}{c}-0.035 \\
(0.058)\end{array}$ \\
\hline$m=10 y, h=12 m$ & $\begin{array}{c}-0.009 \\
(0.125)\end{array}$ & $\begin{array}{c}-0.295^{*} \\
(0.144)\end{array}$ & $\begin{array}{c}-0.117 \\
(0.081)\end{array}$ & $\begin{array}{c}-0.335^{* *} \\
(0.127)\end{array}$ \\
\hline \multicolumn{5}{|c|}{ Panel B: Squared errors } \\
\hline$m=3 \mathrm{~m}, h=3 \mathrm{~m}$ & $\begin{array}{c}-0.254 \\
(0.281)\end{array}$ & $\begin{array}{c}-0.574^{*} \\
(0.278)\end{array}$ & $\begin{array}{c}-0.266 \\
(0.306)\end{array}$ & $\begin{array}{c}-0.432 \\
(0.244)\end{array}$ \\
\hline$m=3 m, h=12 m$ & $\begin{array}{c}-1.427 \\
(0.756)\end{array}$ & $\begin{array}{c}-3.126^{*} \\
(1.275)\end{array}$ & $\begin{array}{c}-1.189 \\
(1.329)\end{array}$ & $\begin{array}{c}-1.996 \\
(1.159)\end{array}$ \\
\hline$m=10 y, h=3 m$ & $\begin{array}{c}0.021 \\
(0.047)\end{array}$ & $\begin{array}{c}-0.067 \\
(0.104)\end{array}$ & $\begin{array}{c}-0.008 \\
(0.053)\end{array}$ & $\begin{array}{c}-0.046 \\
(0.058)\end{array}$ \\
\hline$m=10 y, h=12 \mathrm{~m}$ & $\begin{array}{c}0.059 \\
(0.238)\end{array}$ & $\begin{array}{c}-0.747^{*} \\
(0.295)\end{array}$ & $\begin{array}{c}-0.256 \\
(0.159)\end{array}$ & $\begin{array}{c}-0.603^{*} \\
(0.234)\end{array}$ \\
\hline
\end{tabular}

NOTE: The table reports estimates of $\beta$ and the corresponding standard errors (in parentheses) from the equation $d_{t, m, h}^{j, k}=L\left(e_{t, m, h}^{j}\right)-L\left(e_{t, m, h}^{k}\right)=\alpha+$ $\beta D_{u m}{ }^{j}+\varepsilon_{t}$, for $j=$ NW, where NW is Norway. The sample period is 1998:06-2013:10. The left-hand-side variable is the difference in the loss function of the CE forecast errors for Norwegian interest rates relative to the loss function for benchmark $k$, for a given maturity $m$ and horizon $h$. The benchmark uses the naive random walk forecast errors $(k=\mathrm{RW})$ for Norwegian interest rates as well as the CE forecast errors for three non-FG countries, Australia $(k=\mathrm{AU})$, Canada $(k=\mathrm{CA})$, and the United Kingdom $(k=\mathrm{UK})$. In Panel $\mathrm{A}$, the forecast error loss function $L($.) is the absolute value of the forecast error; in Panel $B$, it is the squared forecast error. The regression uses two interest rates, the 3-month bill rate $(m=3 \mathrm{~m})$ and 10 -year bond rate $(m=10 \mathrm{y})$, at two forecast horizons, 3 months $(h=3 \mathrm{~m})$ and 12 months $(h=12 \mathrm{~m})$. Dum ${ }^{j}$ takes a value of 1 for the FG period in Norway (2005:01-2013:10) and zero otherwise. A negative value of $\hat{\beta}$ implies CE forecast performance for Norway improved with the start of FG relative to the given benchmark. ${ }^{*}{ }^{* *}$ indicate significance at the 5 percent/ 1 percent levels.

constant after late 2007, which could bias the results in favor of the random-walk model. However, when the equation was estimated using data ending December 2006, the results were qualitatively identical to those reported here. ${ }^{16}$ Overall, the evidence does not point to a clear improvement of interest rate predictability in New Zealand (up to a horizon of 12 months) after introducing FG.

The results for Norway (Table 3 ) are only a bit more supportive of the efficacy of FG. There are eight significantly negative estimates of $\beta$ coefficients and no significantly positive ones. However, six of the eight significantly negative coefficients are for the Australian benchmark. None are statistically significant relative to the random-walk benchmark. The fact that the results are strongly supportive of the efficacy of FG relative to only the Australian benchmark raises serious doubts about the efficacy of Norway's FG. 


\section{Table 4}

Relative Changes in Survey Forecast Performance: Sweden

\begin{tabular}{|c|c|c|c|c|}
\hline \multirow[b]{2}{*}{ Maturity, horizon } & \multicolumn{4}{|c|}{ Benchmark } \\
\hline & RW & $A U$ & CA & UK \\
\hline \multicolumn{5}{|c|}{ Panel A: Absolute errors } \\
\hline$m=3 m, h=3 m$ & $\begin{array}{c}-0.079 \\
(0.072)\end{array}$ & $\begin{array}{c}-0.090 \\
(0.084)\end{array}$ & $\begin{array}{c}0.136 \\
(0.088)\end{array}$ & $\begin{array}{c}-0.019 \\
(0.070)\end{array}$ \\
\hline$m=3 m, h=12 m$ & $\begin{array}{r}-0.446^{*} \\
(0.177)\end{array}$ & $\begin{array}{c}-0.426 \\
(0.237)\end{array}$ & $\begin{array}{c}0.027 \\
(0.243)\end{array}$ & $\begin{array}{c}-0.109 \\
(0.206)\end{array}$ \\
\hline$m=10 y, h=3 m$ & $\begin{array}{c}0.058 \\
(0.052)\end{array}$ & $\begin{array}{c}0.018 \\
(0.070)\end{array}$ & $\begin{array}{c}0.054 \\
(0.065)\end{array}$ & $\begin{array}{c}-0.060 \\
(0.065)\end{array}$ \\
\hline$m=10 \mathrm{y}, h=12 \mathrm{~m}$ & $\begin{array}{c}0.206 \\
(0.125)\end{array}$ & $\begin{array}{c}-0.197 \\
(0.126)\end{array}$ & $\begin{array}{c}-0.198 \\
(0.123)\end{array}$ & $\begin{array}{c}-0.230 \\
(0.118)\end{array}$ \\
\hline \multicolumn{5}{|c|}{ Panel B: Squared errors } \\
\hline$m=3 m, h=3 m$ & $\begin{array}{c}-0.234 \\
(0.255)\end{array}$ & $\begin{array}{c}-0.115 \\
(0.144)\end{array}$ & $\begin{array}{c}0.269 \\
(0.199)\end{array}$ & $\begin{array}{c}-0.034 \\
(0.085)\end{array}$ \\
\hline$m=3 m, h=12 m$ & $\begin{array}{c}-1.439 * \\
(0.650)\end{array}$ & $\begin{array}{c}-1.551 \\
(0.891)\end{array}$ & $\begin{array}{c}0.173 \\
(0.816)\end{array}$ & $\begin{array}{c}-0.809 \\
(0.681)\end{array}$ \\
\hline$m=10 y, h=3 \mathrm{~m}$ & $\begin{array}{c}0.112 \\
(0.083)\end{array}$ & $\begin{array}{c}-0.023 \\
(0.103)\end{array}$ & $\begin{array}{c}0.106 \\
(0.097)\end{array}$ & $\begin{array}{c}-0.024 \\
(0.103)\end{array}$ \\
\hline$m=10 \mathrm{y}, h=12 \mathrm{~m}$ & $\begin{array}{c}0.433 \\
(0.314)\end{array}$ & $\begin{array}{c}-0.585 \\
(0.306)\end{array}$ & $\begin{array}{c}-0.584 \\
(0.321)\end{array}$ & $\begin{array}{c}-0.551 \\
(0.283)\end{array}$ \\
\hline
\end{tabular}

NOTE: The table reports estimates of $\beta$ and the corresponding standard errors (in parentheses) from the equation $d_{t, m, h}^{j, k}=L\left(e_{t, m, h}^{j}\right)-L\left(e_{t, m, h}^{k}\right)=\alpha+$ $\beta D u m^{j}+\varepsilon_{t}$, for $j=S W$, where SW is Sweden. The sample period is 1995:01-2013:10. The left-hand-side variable is the difference in the loss function of the CE forecast errors for Swedish interest rates relative to the loss function for benchmark $k$, for a given maturity $m$ and horizon $h$. The benchmark uses the naive random walk forecast errors $(k=\mathrm{RW})$ for Swedish interest rates as well as the CE forecast errors for three non-FG countries, Australia $(k=\mathrm{AU})$, Canada $(k=\mathrm{CA})$, and the United Kingdom $(k=\mathrm{UK})$. In Panel A, the forecast error loss function $L($.$) is the absolute value of the$ forecast error; in Panel $B$, it is the squared forecast error. The regression uses two interest rates, the 3-month bill rate $(\mathrm{m}=3 \mathrm{~m})$ and 10 -year bond rate $(m=10 \mathrm{y})$, at two forecast horizons, 3 months $(h=3 \mathrm{~m})$ and 12 months $(h=12 \mathrm{~m})$. Dum ${ }^{j}$ takes a value of 1 for the FG period in Sweden (2007:02-2013:10) and zero otherwise. A negative value of $\hat{\beta}$ implies CE forecast performance for Sweden improved with the start of FG relative to the given benchmark. *** indicate significance at the 5 percent/ 1 percent levels.

The results for Sweden (Table 4) provide no support for the effectiveness of the Riksbank's FG. Only 2 of the 32 estimated coefficients were significantly negative-both relative to the random-walk benchmark. ${ }^{17}$ Overall, the results for New Zealand, Norway, and Sweden suggest that the FG provided by these three central banks had little if any effect on the predictability of short- or long-term rates.

The United States. In contrast with the other three countries in our analysis, the FOMC did not announce an explicit path for it policy rate. However, it provided implicit FG from August 2003 through December 2005 and again from December 2008 onward. We investigate whether the Fed's FG increased market participants' ability to predict interest rates by estimating 


\section{Table 5}

Relative Changes in Survey Forecast Performance: United States

\begin{tabular}{|c|c|c|c|c|c|c|c|c|}
\hline \multirow[b]{2}{*}{ Maturity, horizon } & \multicolumn{2}{|c|}{ RW } & \multicolumn{2}{|c|}{$A U$} & \multicolumn{2}{|c|}{ CA } & \multicolumn{2}{|c|}{ UK } \\
\hline & $\hat{\beta}_{1}$ & $\hat{\beta}_{2}$ & $\hat{\beta}_{1}$ & $\hat{\beta}_{2}$ & $\hat{\beta}_{1}$ & $\hat{\beta}_{2}$ & $\hat{\beta}_{1}$ & $\hat{\beta}_{2}$ \\
\hline \multicolumn{9}{|c|}{ Panel A: Absolute errors } \\
\hline$m=3 \mathrm{~m}, h=3 \mathrm{~m}$ & $\begin{array}{c}-0.297^{* *} \\
(0.091)\end{array}$ & $\begin{array}{c}0.063^{*} \\
(0.026)\end{array}$ & $\begin{array}{c}0.096 \\
(0.087)\end{array}$ & $\begin{array}{c}-0.113 \\
(0.077)\end{array}$ & $\begin{array}{c}0.124 \\
(0.093)\end{array}$ & $\begin{array}{l}0.171 * \\
(0.082)\end{array}$ & $\begin{array}{c}-0.017 \\
(0.084)\end{array}$ & $\begin{array}{c}-0.098 \\
(0.085)\end{array}$ \\
\hline$m=3 m, h=12 m$ & $\begin{array}{c}-1.268^{* *} \\
(0.142)\end{array}$ & $\begin{array}{c}0.173 \\
(0.114)\end{array}$ & $\begin{array}{c}0.482^{*} \\
(0.238)\end{array}$ & $\begin{array}{c}-0.352 \\
(0.296)\end{array}$ & $\begin{array}{c}0.169 \\
(0.183)\end{array}$ & $\begin{array}{l}-0.066 \\
(0.203)\end{array}$ & $\begin{array}{c}-0.047 \\
(0.216)\end{array}$ & $\begin{array}{r}-0.384^{*} \\
(0.196)\end{array}$ \\
\hline$m=10 y, h=3 m$ & $\begin{array}{c}0.019 \\
(0.073)\end{array}$ & $\begin{array}{c}0.020 \\
(0.045)\end{array}$ & $\begin{array}{c}0.077 \\
(0.066)\end{array}$ & $\begin{array}{c}0.046 \\
(0.095)\end{array}$ & $\begin{array}{c}-0.051 \\
(0.064)\end{array}$ & $\begin{array}{l}0.098^{*} \\
(0.048)\end{array}$ & $\begin{array}{c}0.045 \\
(0.062)\end{array}$ & $\begin{array}{c}0.032 \\
(0.059)\end{array}$ \\
\hline$m=10 y, h=12 m$ & $\begin{array}{c}0.131 \\
(0.195)\end{array}$ & $\begin{array}{c}0.228 \\
(0.191)\end{array}$ & $\begin{array}{c}0.340^{* *} \\
(0.129)\end{array}$ & $\begin{array}{c}0.222 \\
(0.167)\end{array}$ & $\begin{array}{c}-0.366^{* *} \\
(0.102)\end{array}$ & $\begin{array}{c}0.077 \\
(0.093)\end{array}$ & $\begin{array}{c}0.060 \\
(0.122)\end{array}$ & $\begin{array}{c}0.020 \\
(0.120)\end{array}$ \\
\hline
\end{tabular}

Panel B: Squared errors

$\begin{array}{lcccccccc}m=3 \mathrm{~m}, h=3 \mathrm{~m} & -0.221^{*} & 0.067 & 0.116 & 0.018 & 0.344^{*} & 0.375^{*} & 0.033 & -0.008 \\ & (0.080) & (0.036) & (0.153) & (0.152) & (0.174) & (0.171) & (0.175) & (0.176) \\ m=3 \mathrm{~m}, h=12 \mathrm{~m} & -3.014^{* *} & -0.023 & 1.141 & 0.005 & 0.419 & 0.117 & -0.647 & 0.913 \\ & (0.494) & (0.256) & (0.945) & (1.001) & (0.578) & (0.598) & (0.733) & -(0.727) \\ m=10 \mathrm{y}, h=3 \mathrm{~m} & 0.015 & 0.037 & 0.181 & 0.101 & -0.009 & 0.166 & 0.085 & 0.116 \\ & (0.053) & (0.065) & (0.104) & (0.153) & (0.086) & (0.088) & (0.097) & (0.104) \\ m=10 \mathrm{y}, h=12 \mathrm{~m} & 0.095 & 0.639 & 1.120^{* *} & 0.875^{*} & -0.666^{* *} & 0.276 & 0.026 & 0.221 \\ & (0.255) & (0.398) & (0.361) & (0.441) & (0.255) & (0.220) & (0.225) & (0.253)\end{array}$

NOTE: The table reports estimates of $\beta_{1}$ and $\beta_{2}$ and the corresponding standard errors (in parentheses) from the equation $d_{t, m, h}^{u s, k}+\alpha+\beta_{1} D u m m_{1}^{u s}+$ $\beta_{2}$ Dum $m_{2}^{u s}+\varepsilon_{t}$, for the United States (US). The sample period is 1990:01-2013:10. The left-hand-side variable is the difference in the loss function of the CE forecast errors for U.S. interest rates relative to the benchmark $k$, for a given maturity $m$ and horizon $h$. For the benchmark, we use the naive random walk forecast errors $(k=\mathrm{RW})$ for U.S. interest rates as well as the CE forecast errors for three non-FG countries, Australia ( $k=\mathrm{AU})$, Canada $(k=C A)$ and the United Kingdom ( $k=U K)$. In Panel A, the forecast error loss function $L($.$) is the absolute value of the forecast error; in Panel B$, it is the squared forecast error. The regression uses two interest rates, the 3-month bill rate $(m=3 \mathrm{~m})$ and 10 -year bond rate ( $m=10 \mathrm{y})$, at two forecast horizons, 3 months $(h=3 \mathrm{~m})$ and 12 months $(h=12 \mathrm{~m})$. Dum ${ }_{1}^{\text {s }}$ takes a value of 1 for the first FG period in the United States (2003:08-2005:12) and zero otherwise. Dum ${ }_{2}^{u s}$ takes a value of 1 for the second FG period in the United States (2009:01-2013:10) and zero otherwise. A negative value of $\hat{\beta}_{1}$ or $\hat{\beta}_{2}$ implies CE forecast performance for U.S. rates improved in the first or second FG period, respectively, relative to the given benchmark.

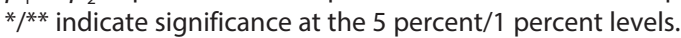

$$
d_{t, m, h}^{u s, k}=\alpha+\beta_{1} D u m_{1}^{u s}+\beta_{2} D u m_{2}^{u s}+\varepsilon_{t},
$$

where $D u m_{1}^{u s}$ is a dummy variable that takes a value of 1 for the August 2003-December 2005 period and zero otherwise and $D u m_{2}^{u s}$ is a dummy variable that takes a value of 1 for the January 2009-October 2013 period and zero otherwise. As before, $k=\mathrm{RW}, \mathrm{AU}, \mathrm{CA}, \mathrm{UK} .{ }^{18}$

Table 5 presents the results for the period January 1990-October 2013. Again, Panel A shows the results for the absolute errors; Panel B shows the results for the squared errors. Compared with the strong support found in Table 1, the results presented in Table 5 provide essentially no support for the efficacy of FG. Of the 64 estimated coefficients in Table 5, only about 30 percent are negative. Moreover, only 16 of the coefficients are statistically significant. Of these, 7 are negative, while 9 are positive. Four of the negative and statistically significant 
coefficients are relative to the random-walk benchmark, and 6 of the 7 are for the first period of FG. Only 1 of the statistically significant coefficients is negative for the second period of FG. Because the second-period results could have been affected by Lehman, we removed the period 2008:7-2009:1 for the 3-month forecasts and the period 2007:12-2009:1 for the 12month forecasts. The results were qualitatively unchanged from the results reported in Table 5 for both FG periods. ${ }^{19}$

\section{FG and Forecast Consensus}

This section investigates the efficacy of the four central banks' FG policy in a different yet complementary way. Because all forecasters have access to the same central bank FG, there should be a marked reduction in cross-sectional forecast variance following the adoption of FG. That is, FG should increase the predictability for all forecasts and, hence, reduce the crosssectional variance. Specifically, we evaluate the efficacy of FG by testing whether there was convergence of market participants' forecasts following the adoption of FG. To do this, we define the cross-sectional standard deviation of the forecasts at time $t$ for country $j$ 's interest rate of maturity $m$, denoted $x_{t, m}$, at horizon $h$ as $^{20}$

$$
c s_{t, m, h}^{j}=\sqrt{\frac{1}{N-1} \sum_{i=1}^{N}\left[f_{t, m, h}^{i, j}-\bar{f}_{t, m, h}^{j}\right]^{2}},
$$

where $i$ is the survey participant index, $N$ is the number of individual survey forecasts, and $\bar{f}$ is the average forecast. That is,

$$
\bar{f}_{t, m, h}^{j}=\frac{1}{N} \sum_{i=1}^{N} f_{t, m, h}^{i, j} .
$$

The standard deviation, cs, is not scale invariant-the higher the current interest rate, the larger the variance (see Mankiw, Reis, and Wolfers, 2004). This variance may be especially important given the zero-lower-bound issue for the United States. To account for this fact, we normalize $c s$ relative to the level of the interest rate being forecast. Our normalized measure of variation is

$$
c s n_{t, m, h}^{j}=c s_{t, m, h}^{j} / x_{t, m}^{j} .
$$

We test whether FG decreased the heterogeneity of forecasts using the following regression equation for $j=\mathrm{NZ}, \mathrm{NW}, \mathrm{SW}$, which is similar to equation $(2)^{21}$ :

$$
d c_{t, m, h}^{j, k}=\operatorname{csn}_{t, m, h}^{j}-\operatorname{csn}_{t, m, h}^{k}=\gamma_{0}+\gamma_{1} D u m^{j}+\omega_{t} .
$$

To control for other factors that may have influenced the degree of forecast convergence, we use three non-FG countries as benchmarks. A negative estimate of $\gamma_{1}$ signals relative convergence of survey forecasts.

The results for New Zealand, Norway, and Sweden (Table 6) provide more support for the efficacy of FG, especially for New Zealand. Eleven of the 12 coefficients are statistically 


\section{Kool and Thornton}

\section{Table 6}

\section{Relative Changes in Survey Forecast Convergence: New Zealand, Norway, and Sweden}

\begin{tabular}{|c|c|c|c|}
\hline Maturity, horizon & $A U$ & CA & UK \\
\hline \multicolumn{4}{|c|}{ Panel A: New Zealand } \\
\hline$m=3 \mathrm{~m}, h=3 \mathrm{~m}$ & $\begin{array}{c}-0.007 \\
(0.006)\end{array}$ & $\begin{array}{c}-0.051^{*} \\
(0.021)\end{array}$ & $\begin{array}{c}-0.087^{* *} \\
(0.018)\end{array}$ \\
\hline$m=3 m, h=12 m$ & $\begin{array}{l}0.031^{* *} \\
(0.008)\end{array}$ & $\begin{array}{c}-0.199 * \\
(0.086)\end{array}$ & $\begin{array}{c}-0.165^{* *} \\
(0.042)\end{array}$ \\
\hline$m=10 y, h=3 \mathrm{~m}$ & $\begin{array}{c}-0.015^{* *} \\
(0.006)\end{array}$ & $\begin{array}{c}-0.014^{* *} \\
(0.004)\end{array}$ & $\begin{array}{c}-0.038^{* *} \\
(0.008)\end{array}$ \\
\hline$m=10 y, h=12 m$ & $\begin{array}{c}-0.020^{* *} \\
(0.008)\end{array}$ & $\begin{array}{c}-0.034^{* *} \\
(0.006)\end{array}$ & $\begin{array}{c}-0.061^{* *} \\
(0.009)\end{array}$ \\
\hline \multicolumn{4}{|l|}{ Panel B: Norway } \\
\hline$m=3 \mathrm{~m}, h=3 \mathrm{~m}$ & $\begin{array}{c}-0.011 \\
(0.009)\end{array}$ & $\begin{array}{c}-0.106^{* *} \\
(0.036)\end{array}$ & $\begin{array}{c}-0.144^{* *} \\
(0.028)\end{array}$ \\
\hline$m=3 m, h=12 m$ & $\begin{array}{c}-0.011 \\
(0.022)\end{array}$ & $\begin{array}{c}-0.400^{*} \\
(0.154)\end{array}$ & $\begin{array}{c}-0.324^{* *} \\
(0.068)\end{array}$ \\
\hline$m=10 y, h=3 m$ & $\begin{array}{c}0.025^{*} \\
(0.010)\end{array}$ & $\begin{array}{c}0.025^{*} \\
(0.011)\end{array}$ & $\begin{array}{c}-0.002 \\
(0.009)\end{array}$ \\
\hline$m=10 y, h=12 m$ & $\begin{array}{c}0.026^{*} \\
(0.011)\end{array}$ & $\begin{array}{c}0.008 \\
(0.008)\end{array}$ & $\begin{array}{c}-0.024 \\
(0.012)\end{array}$ \\
\hline \multicolumn{4}{|l|}{ Panel C: Sweden } \\
\hline$m=3 \mathrm{~m}, h=3 \mathrm{~m}$ & $\begin{array}{l}0.062^{* *} \\
(0.019)\end{array}$ & $\begin{array}{c}-0.056^{*} \\
(0.026)\end{array}$ & $\begin{array}{c}-0.099 * * \\
(0.020)\end{array}$ \\
\hline$m=3 m, h=12 m$ & $\begin{array}{c}0.144^{*} \\
(0.071)\end{array}$ & $\begin{array}{c}-0.343^{* *} \\
(0.121)\end{array}$ & $\begin{array}{c}-0.239 * * \\
(0.049)\end{array}$ \\
\hline$m=10 y, h=3 \mathrm{~m}$ & $\begin{array}{l}0.046^{* *} \\
(0.008)\end{array}$ & $\begin{array}{l}0.044^{* *} \\
(0.010)\end{array}$ & $\begin{array}{c}0.010 \\
(0.007)\end{array}$ \\
\hline$m=10 y, h=12 m$ & $\begin{array}{l}0.075^{* *} \\
(0.014)\end{array}$ & $\begin{array}{l}0.057^{* *} \\
(0.013)\end{array}$ & $\begin{array}{c}0.012 \\
(0.012)\end{array}$ \\
\hline
\end{tabular}

NOTE: The table reports estimates of $\gamma_{1}$ and its standard errors (in parentheses) from the equation $d c_{t, m, h}^{j, k}=c s n_{t, m, h}^{j}-\operatorname{csn}_{t, m, h}^{k}=\gamma_{0}+\gamma_{1} D u m^{j}+\omega_{t}$, for $j=$ NZ (Panel A), $j=$ NW (Panel B), and $j=$ SW (Panel C), where NZ is New Zealand, NW is Norway, and SW is Sweden. The sample period starts in 1994:12 for New Zealand, in 1995:01 for Sweden, and in 1998:06 for Norway. The sample period ends in 2013:10. The left-hand-side variable is the difference between the normalized cross-sectional standard deviation of the CE forecast errors of country $j$ and the normalized cross-sectional standard deviation of the CE forecast errors of non-FG country $k$, with $k=\mathrm{AU}, \mathrm{CA}$, UK, where AU is Australia, CA is Canada, and UK is the United Kingdom, for a given interest rate maturity $m$ and forecast horizon $h$. The regression uses two interest rates, the 3 -month bill rate $(m=3 \mathrm{~m})$ and 10-year bond rate $(m=10 \mathrm{y})$, at two forecast horizons, 3 months $(h=3 \mathrm{~m})$ and 12 months $(h=12 \mathrm{~m})$. Dum ${ }^{j}$ takes a value of 1 for the FG period in country $j$ and zero otherwise. A negative value of $\hat{\gamma}_{1}$ implies CE interest rate forecasts for country $j$ converged with the start of FG relative to those forecasts in country $k .{ }^{*}{ }^{* *}$ indicate significance at the 5 percent/ 1 percent levels. 
Kool and Thornton

\section{Table 7}

\section{Relative Changes in Survey Forecast Convergence: United States}

\begin{tabular}{|c|c|c|c|c|c|c|}
\hline \multirow[b]{2}{*}{ Maturity, horizon } & \multicolumn{2}{|c|}{$A U$} & \multicolumn{2}{|c|}{$C A$} & \multicolumn{2}{|c|}{ UK } \\
\hline & $\hat{\gamma}_{1}$ & $\hat{\gamma}_{2}$ & $\hat{\gamma}_{1}$ & $\hat{\gamma}_{2}$ & $\hat{\gamma}_{1}$ & $\hat{\gamma}_{2}$ \\
\hline$m=3 m, h=3 m$ & $\begin{array}{c}-0.159 \\
(0.198)\end{array}$ & $\begin{array}{c}0.878^{*} \\
(0.363)\end{array}$ & $\begin{array}{c}-0.158 \\
(0.187)\end{array}$ & $\begin{array}{c}0.733^{*} \\
(0.360)\end{array}$ & $\begin{array}{c}-0.154 \\
(0.187)\end{array}$ & $\begin{array}{c}0.672 \\
(0.362)\end{array}$ \\
\hline$m=3 m, h=12 m$ & $\begin{array}{c}-0.271 \\
(0.430)\end{array}$ & $\begin{array}{l}3.125^{* *} \\
(0.987)\end{array}$ & $\begin{array}{c}-0.329 \\
(0.404)\end{array}$ & $\begin{array}{l}2.463^{* *} \\
(0.927)\end{array}$ & $\begin{array}{c}-0.263 \\
(0.407)\end{array}$ & $\begin{array}{c}2.624^{* *} \\
(0.965)\end{array}$ \\
\hline$m=10 \mathrm{y}, h=3 \mathrm{~m}$ & $\begin{array}{l}0.012^{* *} \\
(0.003)\end{array}$ & $\begin{array}{l}0.028^{* *} \\
(0.007)\end{array}$ & $\begin{array}{c}-0.008^{*} \\
(0.003)\end{array}$ & $\begin{array}{l}0.024^{* *} \\
(0.006)\end{array}$ & $\begin{array}{c}0.006 \\
(0.004)\end{array}$ & $\begin{array}{c}-0.015^{* *} \\
(0.004)\end{array}$ \\
\hline$m=10 \mathrm{y}, h=12 \mathrm{~m}$ & $\begin{array}{l}0.015^{*} \\
(0.007)\end{array}$ & $\begin{array}{l}0.081^{* *} \\
(0.012)\end{array}$ & $\begin{array}{l}-0.019 * * \\
(0.006)\end{array}$ & $\begin{array}{l}0.054^{* *} \\
(0.010)\end{array}$ & $\begin{array}{l}0.021^{* *} \\
(0.006)\end{array}$ & $\begin{array}{c}0.007 \\
(0.008)\end{array}$ \\
\hline
\end{tabular}

NOTE: The table reports estimates of $\gamma_{1}$ and $\gamma_{2}$ and their standard errors in parentheses from the equation $d c_{t, m, h}^{u s, k}=\operatorname{cs}_{t, m, h}^{u s}-\operatorname{csn}_{t, m, h}^{k}=\gamma_{0}+\gamma_{1} D u m_{1}^{\text {us }}+$ $\gamma_{2}$ Dum $_{2}^{u s}+\omega_{t}$ for the United States (US). The sample period is 1990:1-2013:10. The left-hand-side variable is the difference between the normalized cross-sectional standard deviation of the CE forecast errors of the United States and the normalized cross-sectional standard deviation of the CE forecast errors of non-FG country $k$, with $k=\mathrm{AU}, \mathrm{CA}$, UK, where AU is Australia, CA is Canada, and UK is the United Kingdom, for a given interest rate maturity $m$ and forecast horizon $h$. The regression uses two interest rates, the 3-month bill rate $(m=3 \mathrm{~m})$ and 10 -year bond rate $(m=10 \mathrm{y})$, at two forecast horizons, 3 months $(h=3 \mathrm{~m})$ and 12 months $(h=12 \mathrm{~m})$. Dum ${ }_{1}^{\text {us }}$ takes a value of 1 for the first FG period in the United States (2003:082005:12) and zero otherwise. Dum us takes a value of 1 for the second FG period in the United States (2009:01-2013:10) and zero otherwise. A negative value of $\hat{\gamma}_{1}$ or $\hat{\gamma}_{2}$ implies CE forecasts for U.S. interest rates converged in the first or second FG period, respectively, relative the given benchmarks. ${ }^{* * *}$ indicate significance at the 5 percent/ 1 percent levels.

significant, and only one is positive. The evidence of convergence is strong for bills and bonds at both horizons.

The results for Norway and Sweden are less definitive. There is evidence of convergence in the bill market relative to Canada and the United Kingdom but not to Australia. For Sweden there is evidence of divergence for bills and bonds at both horizons. For Norway there is evidence of divergence for the bond market. Hence, the evidence for convergence is much stronger for bills than bonds, which is what one might suspect. The results are qualitatively the same when the Lehman period is excluded from the estimation.

The results for the United States (Table 7) show no evidence of increased convergence for either FG period. In the first period, all coefficients for the bill rate are insignificant, while those for the bond yield are a mix of positive and negative significant coefficients. In the second period, 9 of 12 coefficients are significantly positive and only 1 is negative, suggesting that forecasts diverged significantly after 2008. This result is unexpected in that the Fed's policy rate was at the zero lower bound over the entire period. A priori, one would think that the zero lower bound should have resulted in greater convergence. The results with the Lehman period excluded (Table 7) remain qualitatively the same for the second FG period. However, for the first FG period, almost all coefficients for the bill rate become significantly positive, indicating more rather than less dispersion in the first period as well.

Overall, evidence with respect to the cross-sectional dispersion of interest rate forecasts suggests that there was a statistically significant increase in convergence of forecasts for both the bill rate and the bond yield after the RBNZ adopted FG. For Norway and Sweden, at best 


\section{Kool and Thornton}

there is some evidence of forecast convergence for short-term rates. Hence, while there is evidence that FG reduced the variability of forecasts across forecasters, there is little or no evidence that it significantly improved their forecast accuracy. For the United Sates, there is essentially no evidence that FG resulted in either convergence or improved forecast accuracy.

\section{SUMMARY AND CONCLUSIONS}

This paper investigates the impact of FG on the predictability of future short- and longterm interest rates in New Zealand, Norway, Sweden, and the United States by comparing survey-forecast accuracy before and after the adoption of FG. Four main findings provide, at best, modest support for the efficacy of FG. First, there is evidence of improved unconditional forecast accuracy following the adoption of FG for New Zealand, but not for Norway or Sweden.

Second, when the improvement in forecast accuracy is tested relative to the random walk and three country benchmarks, there is some evidence of increased predictability for the short-term policy rate, especially at the short horizons, for New Zealand, Norway, and Sweden. However, many of the estimates were small and few were statistically significant. Moreover, there was no uniformity of results across the four benchmarks.

Third, there is evidence that FG resulted in greater convergence of survey participants' forecasts for the short-term rate for New Zealand and somewhat weaker evidence for Norway and Sweden. Unfortunately, the greater convergence was not accompanied by a corresponding improvement in forecast accuracy.

Fourth, there is no evidence of greater convergence or improved forecast accuracy for either period of FG in the United States. If anything, the evidence suggests a deterioration of forecasting performance following the second period of FG. 


\section{NOTES}

1 We selected only these four countries as they have a long-enough history of relevant FG observations. The Czech Republic has the next-longest FG experience, but its financial markets and institutions are less developed than those in the other countries we study.

2 Woodford (2012, p. 189) makes a similar statement.

3 The Woodford period is not a specified length. If the central bank had been using a policy rule to set the policy rate, the Woodford period would be the length of time the central bank held the rate after the policy rule would have indicated it should have been increased. How long this would be maintained, of course, is not specified.

4 Goodhart (2009) raises similar practical concerns about the feasibility and effectiveness of FG.

5 However, it could be that policymakers revised their projected path based on observed behavior of rates during the period between the two successive FG announcements (e.g., Andersson and Hofmann, 2010).

6 Archer (2005, p. 4, footnote 13) states that the choice to publish the path for the bill rate rather than the policy rate is due to historical reasons and has only second-order implications overshadowed by the uncertainty surrounding the policy path itself.

7 Since 2013, the Norges Bank has been issuing reports four times per year.

8 The FOMC first discussed the possibility of having a larger effect on long-term yields via Woodford's (1999) policy inertia suggestion at its January 2003 FOMC meeting (see Thornton, 2012).

9 All quotes of FOMC meeting announcements are from Federal Reserve monetary policy press releases available at http://www.federalreserve.gov/newsevents/press/monetary/2015monetary.htm.

${ }^{10}$ Woodford (2005, p. 400) referred to this as the Fed's "bold recent experiment in greater explicitness about the future outlook for interest rates."

${ }^{11}$ Unreported tests show that the interest rate projections of the central banks of New Zealand, Norway, and Sweden generally outperform naive random-walk forecasts. However, the gain is typically small and significant only for horizons of up to three quarters ahead. For the United States, numerical central bank forecasts have been unavailable until very recently.

${ }^{12}$ For the sake of brevity, we do not report full regression results. They are available upon request.

${ }^{13}$ The zero-lower-bound issue is particular to the short-term rate in the United States. Only two countries in our sample had short-term rates drop below 0.5: Canada (during most of 2009 and early 2010) and Sweden (during 2009). The United Kingdom and Sweden both had short spells of short-term interest rate levels between 0.5 and 1 percent. For Norway, Australia, and New Zealand, short-term rates stayed away from exceptionally low levels over the sample.

${ }^{14}$ For the random-walk benchmark, we compare the survey forecasts made in month $t$ for the end of months $t+3$ and $t+12$ with the rate observed on the last working day of month $t-1$.

${ }^{15}$ For the Bank of Canada, a caveat applies with respect to its classification as a non-FG country. It used qualitative FG in 2009-10 as an exceptional measure because interest rates were close to the zero lower bound. However, it did not provide interest rate forecasts. The Bank of England adopted FG only in 2013. Our sample ends in October 2013. Unreported results show that limiting the analysis to the period prior to the adoption of FG by the Bank of Canada and the Bank of England leaves the results virtually the same.

16 Since Norway and Sweden started FG only in late 2005 and early 2007, respectively, we are unable to do the same robustness test for these countries.

17 Similar to the analysis for Table 1, we reran the estimation for Tables 2 through 4 excluding the Lehman period. In contrast to the results for Table 1, the results for Tables 2 through 4 remain qualitatively the same, which suggests that the double differencing already sufficiently controls for the Lehman-period volatility. Results are available upon request.

${ }^{18}$ Alternatively, we used Blue Chip Financial forecasts in place of the CE forecasts and the results are virtually identical.

${ }^{19}$ These results are available upon request. 


\section{Kool and Thornton}

20 It is straightforward to show that the cross-sectional standard deviation of survey forecasts equals the crosssectional standard deviation of survey forecast errors, independent of the realization of the forecasted variable.

${ }^{21}$ For the United States, the equation is extended to include two dummy variables, similar to equation (3).

\section{REFERENCES}

Amato, Jeffery D.; Morris, Stephen and Shin, Hyun Song. "Communication and Monetary Policy." Oxford Review of Economic Policy, December 2002, 18(4), pp. 495-503; http://oxrep.oxfordjournals.org/content/18/4/495.abstract.

Andersson, Magnus and Hofmann, Boris. "Gauging the Effectiveness of Quantitative Forward Guidance: Evidence from Three Inflation Targeters," in David Cobham, Øyvind Eitrheim, Stefan Gerlach, and Jan F. Qvigstad, eds., Twenty Years of Inflation Targeting: Lessons Learned and Future Prospects. Chap. 15. Cambridge, UK: Cambridge University Press, 2010, pp. 368-97.

Archer, David. "Central Bank Communication and the Publication of Interest Rate Projections." Prepared for the Sveriges Riksbank conference Inflation Targeting: Implementation, Communication and Effectiveness, Stockholm, June 2005; http://www.riksbank.se/Upload/Dokument_riksbank/Kat_foa/Archer17May.pdf.

Bergo, Jarle. "Projections, Uncertainty and Choice of Interest Rate Assumption in Monetary Policy." Norges Bank Economic Bulletin, April 2006, LXXVII(1/2006), pp. 16-23;

http://www.norges-bank.no/en/Published/Papers/Economic-Bulletin/Economic-Bulletin-12006/.

Bernanke, Ben S. "Federal Reserve Communications." Presented at the Cato Institute 25th Annual Monetary Conference, Washington, DC, November 14, 2007;

http://www.federalreserve.gov/newsevents/speech/bernanke20071114a.htm.

Blinder, Alan S. and Wyplosz, Charles. "Central Bank Talk: Committee Structure and Communication Policy." Prepared for the ASSA meetings, Philadelphia, January 9, 2005, December 2004; https://www.aeaweb.org/assa/2005/0109_1015_0702.pdf.

Brzoza-Brzezina, Michal and Kot, Adam. "The Relativity Theory Revisited: Is Publishing Interest Rate Forecasts Really So Valuable?" MPRA Working Paper No. 10296, Munich Personal RePEc Archive, July 2008; http://mpra.ub.uni-muenchen.de/10296/1/MPRA_paper_10296.pdf.

Campbell, Jeffrey R.; Evans, Charles; Fisher, Jonas D.M. and Justiniano, Alejandro. "Macroeconomic Effects of Federal Reserve Forward Guidance." Working Paper No. 2012-03, Federal Reserve Bank of Chicago, Spring 2012; https://www.chicagofed.org/publications/working-papers/2012/wp-03.

Detmers, Gunda-Alexandra and Nautz, Dieter. "The Information Content of Central Bank Interest Rate Projections: Evidence from New Zealand." Discussion Paper Series DP2012/03, Reserve Bank of New Zealand, February 2012; http://www.rbnz.govt.nz/research_and_publications/discussion_papers/2012/dp12_3.pdf.

Drew, Aaron and Karagedikli, Özer. "Some Benefits of Monetary Policy Transparency in New Zealand." Discussion Paper Series DP2008/01, Reserve Bank of New Zealand, January 2008; http://www.rbnz.govt.nz/research_and_publications/discussion_papers/2008/dp08_01.pdf.

Ferrero, Giuseppe and Secchi, Alessandro. "The Announcement of Future Policy Intentions." Working paper, Bank of Italy, May 2007; https://www.bancaditalia.it/pubblicazioni/altri-atti-convegni/2007-iii-conf-moneybanking/Secchi.pdf?language_id=1.

Gersbach, Hans and Hahn, Volker. "Monetary Policy Inclinations." CEPR Discussion Paper No. 6761, Centre for Economic and Policy Research, March 2008a.

Gersbach, Hans and Hahn, Volker. "Forward Guidance for Monetary Policy: Is It Desirable?" CER-ETH Economics Working Paper Series No. 08/84, Center of Economic Research at ETH Zurich, April 2008b.

Goodhart, Charles A.E. "The Monetary Policy Committee's Reaction Function: An Exercise in Estimation." B.E. Journals in Macroeconomics: Topics in Macroeconomics, August 2005, 5(1), pp. 1-40; http://down.cenet.org.cn/upfile/34/200846144936198.pdf. 
Goodhart, Charles A.E. "The Interest Rate Conditioning Assumption." International Journal of Central Banking, June 2009, 5(2), pp. 85-108; http://www.ijcb.org/journal/ijcb09q2a3.pdf.

Goodhart, Charles A.E. and Lim, Wen Bin. "Interest Rate Forecasts: A Pathology." International Journal of Central Banking, June 2011, 7(2), pp. 135-72; http://www.ijcb.org/journal/ijcb11q2a5.pdf.

Gosselin, Pierre; Lotz, Aileen and Wyplosz, Charles. "How Much Information Should Interest Rate-Setting Central Banks Reveal?" CEPR Discussion Paper No. 5666, Centre for Economic Policy Research, May 2006; http://www.cepr.org/active/publications/discussion_papers/dp.php?dpno=5666.

Gosselin, Pierre; Lotz, Aileen and Wyplosz, Charles. "Interest Rate Signals and Central Bank Transparency," in Richard Clarida and Francesco Giavazzi, eds., NBER International Seminar on Macroeconomics 2007. Chicago: University of Chicago Press, January 2009, pp. 9-51; http://www.nber.org/chapters/c2997.pdf.

Issing, Otmar. "Communication, Transparency, Accountability—Monetary Policy in the Twenty-First Century." Federal Reserve Bank of St. Louis Review, March/April 2005, 87(2, Part 1), pp. 65-83; https://research.stlouisfed.org/publications/review/05/03/part1/lssing.pdf.

Karagedikli, Özer and Siklos, Pierre L. "Explaining Movements in the NZ Dollar: Central Bank Communication and the Surprise Element in Monetary Policy?" Discussion Paper Series DP2008/02, Reserve Bank of New Zealand, January 2008; http://www.rbnz.govt.nz/research_and_publications/discussion_papers/2008/dp08_02.pdf.

Kohn, Donald L. "Central Bank Communications." Remarks at the Annual Meeting of the American Economic Association, Philadelphia, PA, January 9, 2005; http://www.federalreserve.gov/boarddocs/Speeches/2005/20050109/default.htm.

Kohn, Donald L. "Recent and Prospective Developments in Monetary Policy Transparency and Communications: A Global Perspective." Presented at the National Association for Business Economics Session, Allied Social Science Associations Annual Meeting, New Orleans, LA, January 5, 2008; http://www.federalreserve.gov/newsevents/speech/kohn20080105a.htm.

Kool, Clemens J.M.; Middeldorp, Menno and Rosenkranz, Stephanie. "Central Bank Transparency and the Crowding Out of Private Information in Financial Markets." Journal of Money, Credit, and Banking, June, 2011, 43(4), pp. 765-74; http://onlinelibrary.wiley.com/doi/10.1111/j.1538-4616.2011.00395.x/epdf.

Mankiw, N. Gregory; Reis, Ricardo and Wolfers, Justin. "Disagreement about Inflation Expectations," in Mark Gertler and Kenneth Rogoff, eds., NBER Macroeconomics Annual 2003. Volume 18. Cambridge, MA: MIT Press, July 2004, pp. 209-70; http://www.nber.org/chapters/c11444.

McCaw, Sharon and Ranchhod, Satish. "The Reserve Bank's Forecasting Performance." Reserve Bank of New Zealand Bulletin, December 2002, 65(4), pp. 5-23; http://www.rbnz.govt.nz/research_and_publications/reserve bank_bulletin/2002/2002dec65_4McCawRanchhod.pdf.

Mirkov, Nikola and Natvik, Gisle James. "Announcement of Interest Rate Forecasts: Do Policymakers Stick to Them?" Working Paper No. 11/2013, Norges Bank Research, April 2013; http://www.norgesbank.no/pages/94099/ Norges_Bank_Working_Paper_2013_11.pdf?v=4/11/201324402PM\&ft=.pdf.

Mishkin, Frederic S. "Can Central Bank Transparency Go Too Far?" NBER Working Paper No. 10829, National Bureau of Economic Research, October 2004; http://www.nber.org/papers/w10829.pdf.

Moessner, Richhild. "Effects of Explicit FOMC Policy Rate Guidance on Market Interest Rates." DNB Working Paper No. 384, De Nederlandsche Bank, July 2013; http://www.dnb.nl/binaries/Working\%20Paper\%20384_tcm46-294337.pdf.

Moessner, Richhild and Nelson, William R. "Central Bank Policy Rate Guidance and Financial Market Functioning." International Journal of Central Banking, December 2008, 4(4), pp. 193-226; http://www.ijcb.org/journal/ijcb08q4a6.pdf.

Morris, Stephen and Shin, Hyun Song. "Social Value of Public Information." American Economic Review, December 2002, 92(5), pp. 1521-34; http://pubs.aeaweb.org/doi/pdfplus/10.1257/000282802762024610.

Rosenberg, Irma. "Monetary Policy and the Riksbank's Communication." Presented at the Swedbank, Stockholm, Sweden, October 8, 2007; http://www.riksbank.se/Pagefolders/31796/071008e.pdf. 


\section{Kool and Thornton}

Rudebusch, Glenn D. and Williams, John C. "Revealing the Secrets of the Temple: The Value of Publishing Central Bank Interest Rate Projections," in John Y. Campbell, ed., Asset Prices and Monetary Policy. Chicago: University of Chicago Press, September 2008, pp. 247-289; http://www.nber.org/chapters/c5373.pdf.

Svensson, Lars E.O. "Social Value of Public Information: Comment: Morris and Shin (2002) Is Actually ProTransparency, Not Con." American Economic Review, March 2006, 96(1), pp. 448-52; http://pubs.aeaweb.org/doi/pdfplus/10.1257/000282806776157650.

Svensson, Lars E.O. "What Have Economists Learned About Monetary Policy Over the Past 50 Years?" Presented at the conference Monetary Policy over Fifty Years, Frankfurt am Main, Germany, September 21, 2007; http://www.riksbank.se/Pagefolders/31697/nr38e.pdf.

Thornton, Daniel L. "Monetary Policy Transparency: Transparent About What?" The Manchester School, September 2003, 71(5), pp. 478-97.

Thornton, Daniel L. "How Did We Get to Inflation Targeting and Where Do We Need to Go to Now? A Perspective from the U.S. Experience." Federal Reserve Bank of St. Louis Review, January/February 2012, 94(1), pp. 65-81; https://research.stlouisfed.org/publications/review/12/01/65-82Thornton.pdf.

Thornton, Daniel L. "The Identification of the Response of Interest Rates to Monetary Policy Actions Using MarketBased Measures of Monetary Policy Shocks." Oxford Economic Papers, January 2014, 66(1), pp. 67-87; http://oep.oxfordjournals.org/content/66/1/67.full.pdf+html.

Thornton, Daniel L. "A Requiem for QE." Cato Institute Policy Analysis No. 783, November 2015a.

Thornton, Daniel L. "The Effectiveness of QE: An Assessment of the Event-Study Evidence." Unpublished manuscript, January 2015b; http://www.dlthornton.com/images/research/The_Effectiveness_of_Quantitative_Easing_January_25_2015.pdf.

Turner, Jane. "An Assessment of Recent Reserve Bank Forecasts." Reserve Bank of New Zealand Bulletin, September 2006, 69(3), pp. 38-43;

http://www.rbnz.govt.nz/research_and_publications/reserve_bank_bulletin/2006/2006sep69_3turner.pdf.

Walsh, Carl E. “Optimal Economic Transparency." International Journal of Central Banking, March 2007, 3(1), pp. 5-36; http://www.ijcb.org/journal/ijcb07q1a1.pdf.

Walsh, Carl E. "Announcements and the Role of Policy Guidance." Federal Reserve Bank of St. Louis Review, July/August 2008, 90(4), pp. 421-42; https://research.stlouisfed.org/publications/review/08/07/Walsh.pdf.

Woodford, Michael. “Optimal Monetary Policy Inertia.” The Manchester School, 1999, 67(Supplement S1), pp. 1-35.

Woodford, Michael. "Monetary Policy in the Information Economy," in Economic Policy and the Information Economy. Proceedings of the symposium sponsored by the Federal Reserve Bank of Kansas City, Jackson Hole, WY, August 30-September 1, 2001. Kansas City, MO: Federal Reserve Bank of Kansas City, 2001, pp. 297-370; https://www.kansascityfed.org/publicat/sympos/2001/papers/S02wood.pdf.

Woodford, Michael. Interest and Prices: Foundations of a Theory of Monetary Policy. Princeton, NJ: Princeton University Press, 2003.

Woodford, Michael. "Central Bank Communication and Policy Effectiveness," in The Greenspan Era: Lessons for the Future. Proceedings of the symposium sponsored by the Federal Reserve Bank of Kansas City, Jackson Hole, WY, August 25-27, 2005. Kansas City, MO: Federal Reserve Bank of Kansas City, 2005, pp. 399-474; https://www.kansascityfed.org/publicat/sympos/2005/pdf/Woodford2005.pdf.

Woodford, Michael. "Methods of Policy Accommodation at the Interest-Rate Lower Bound," in The Changing Policy Landscape. Proceedings of the symposium sponsored by the Federal Reserve Bank of Kansas City, Jackson Hole, WY, August 30-September 1, 2012. Kansas City, MO: Federal Reserve Bank of Kansas City, 2012, pp. 185-288; https://www.kansascityfed.org/publicat/sympos/2012/Woodford_final.pdf. 